\title{
Increasing Water Use Efficiency in Vegetable Crop Production: From Plant to Irrigation Systems Efficiency
}

\author{
Stefania De Pascale ${ }^{1}$, Luisa Dalla Costa ${ }^{2}$, Simona Vallone $^{1}$, \\ Giancarlo Barbieri ${ }^{1}$, and Albino Maggio ${ }^{1,3}$
}

ADDITIONAL INDEX WORDs. crop water requirements, evapotranspiration, irrigation methods

\begin{abstract}
SUMMARY. Irrigation is a vital component of the world agriculture. It is practiced worldwide on $\approx 270$ million hectares and it consents to produce $40 \%$ of our total food. Agricultural water consumption accounts for $70 \%$ of total freshwater use. The competition for this precious resource is increasing tremendously. Therefore, it is becoming critically important to optimize agricultural water use efficiency (WUE) defined as the ratio of crop yield over the applied water. This requires a shift from maximizing productivity per unit of land area to maximizing productivity per unit of water consumed. To maximize WUE it is necessary to conserve water and to promote maximal crop growth. The former requires minimizing losses through runoff, seepage, evaporation, and transpiration by weeds. The latter objective may be accomplished by planting high-yielding crops/cultivars well adapted to local soil and climatic conditions. Optimizing growing conditions by proper timing of planting and harvesting, tillage, fertilization, and pest control also contribute to improve crop growth. Most of these techniques refer to proven technology, whose implementation and/or fine-tuning in current farming systems may tremendously improve water management efficiency. In this paper, after discussing the importance of irrigation in agriculture, we will introduce basic concepts that define crop WUE and will finally review the means to improve irrigation efficiency in field vegetable crop production.
\end{abstract}

\section{Importance of irrigation in agriculture}

Irrigated agriculture extends over 270 million hectares (Morison et al., 2008). Although it represents only $17 \%$ of the world cultivated area, it provides $40 \%$ to $45 \%$ of the world food and fiber supply (Evans and Sadler, 2008). Irrigated areas are increasing at a very slow rate ( $1.3 \%$ per year) compared with the years $1960-80(2.6 \%$ to $3.0 \%)$ (Postel, 1999). Nevertheless, irrigated agriculture is the major consumer of available fresh water worldwide and its consumption is estimated at $\approx 70 \%$ of the existing freshwater supplies (Evans and Sadler, 2008). In addition, there is a general perception that agriculture

\footnotetext{
This work was part of the workshop "Improvement in Nitrogen and Water Use Efficiency: Interest of Assessment Tools" held on 16 Sept. 2008 at the European Society for Agronomy Congress, Bologna, Italy.

This research was supported by the research project AZORT "La concimazione AZotata degli ORTaggi."

${ }^{1}$ Department of Agricultural Engineering and Agronomy, University of Naples Federico II, Via Università, 100-80055-Portici (Naples) Italy

${ }^{2}$ Department of Agricultural and Environmental Sciences, University of Udine, Italy

${ }^{3}$ Corresponding author. E-mail: almaggio@unina.it.
}

water use is often wasteful and highly inefficient (Hsiao et al., 2007).

Water used by crops in semiarid environments is only a relative small percentage of the available water. It has been estimated that rain fed crops use $15 \%$ to $30 \%$ of rainfall (Wallace, 2000 ), whereas irrigated crops use only $13 \%$ to $18 \%$ of the available water in similar environments (Wallace and Gregory, 2002 ). Even lower values ( $5 \%$ of total available water) were reported for western Africa by Rockström and Falkenmark (2000). The competing uses for water (domestic, industrial, and environmental) and the increasing demand for food due to a rapidly growing world population require an urgent improvement of productivity per unit of water consumed in agriculture (Food and Agriculture Organization of the United Nations, 2002). This can be accomplished by both advancing our understanding of the physiology and molecular basis of plant WUE and implementing current knowledge to improve WUE in agricultural productions. In the following sections, after addressing the concept of WUE in the context of agricultural systems, we discuss strategies to improve irrigation efficiency in vegetable crop production. We refer to recently published literature for in-depth analyses on the physiology and molecular biology of WUE (Hsiao et al., 2007; Yoo et al., 2009).

\section{Efficiency in the context of agricultural irrigation}

Efficiency has been defined as the ability to produce the desired effect with the minimum effort, expenses, and waste (Jensen, 2007). It is measured as the ratio between the energy expended (input) and the work done (output). Several authors have debated the applicability of this general concept to agricultural WUE since crop production involves multiple and interacting factors that cannot be described by a simple input/output system. In addition, the amount of water that is not used by the plant (via transpiration) cannot necessarily be considered as wasted (Jensen, 2007). In semiarid environments, for instance, soil salinity has to be controlled by soil leaching, and the quantity of water required to flush soil salts below the root zone should also be taken into account for

\begin{tabular}{lllc}
\hline $\begin{array}{l}\text { Units } \\
\begin{array}{l}\text { To convert U.S. to SI, } \\
\text { multiply by }\end{array}\end{array}$ & U.S. unit & SI unit & $\begin{array}{l}\text { To convert SI to U.S., } \\
\text { multiply by }\end{array}$ \\
\hline 0.4047 & $\mathrm{acre}(\mathrm{s})$ & $\mathrm{ha}$ & 2.4711 \\
1 & $\mathrm{cbar}$ & $\mathrm{kPa}$ & 1 \\
0.3048 & $\mathrm{ft}$ & $\mathrm{m}$ & 3.2808 \\
0.0929 & $\mathrm{ft}^{2}$ & $\mathrm{M}^{2}$ & 10.7639 \\
0.0283 & $\mathrm{ft}^{3}$ & $\mathrm{M}^{3}$ & 35.3147 \\
0.0700 & $\mathrm{ft}^{3} / \mathrm{acre}$ & $\mathrm{m}^{3} \cdot \mathrm{ha}^{-1}$ & 14.2913 \\
2.54 & inch $(\mathrm{es})$ & $\mathrm{cm}$ & 0.3937 \\
25.4 & inch $(\mathrm{es})$ & $\mathrm{mm}$ & 0.0394 \\
1.1209 & $\mathrm{lb} / \mathrm{acre}$ & $\mathrm{kg} \cdot \mathrm{ha}^{-1}$ & 0.8922 \\
16.0185 & $\mathrm{lb} / \mathrm{ft}^{3}$ & $\mathrm{~kg} \cdot \mathrm{m}^{-3}$ & 0.0624 \\
0.001 & $\mathrm{ppm}$ & $\mathrm{mg} \cdot \mathrm{g}^{-1}$ & 1000 \\
1 & $\mathrm{ppm}$ & $\mu \mathrm{g} \cdot \mathrm{g}^{-1}$ & 1 \\
2.2417 & ton $/ \mathrm{acre}$ & $\mathrm{Mg} \cdot \mathrm{ha}^{-1}$ & 0.4461
\end{tabular}


sustainable irrigated agriculture (Jensen, 2007). Moreover, efficient use of water in agriculture is a complex subject that involves a broad range of disciplines, including plant physiology, agronomy, and engineering. In this respect, efficiency means transpiration efficiency to physiologists, irrigation efficiency to agronomists, and water application efficiency to engineers (Hsiao et al., 2007). Also, the units used to measure efficiency are not always easy to compare. For example, physiologists refer, at leaf-plant scale, to micrograms or milligrams of carbon dioxide $\left(\mathrm{CO}_{2}\right)$ absorbed per grams of transpired water with a time scale of seconds; agronomists refer to WUE in terms of kilograms of biomass produced (or harvested yield) per cubic meter of water applied with a time scale of days, growth stage, or growth season. At farm level, the water application efficiency is measured in cubic meters of applied water per cubic meter of water used and the time span is usually the growth season or one year (Sinclair et al., 1984). Different definitions, dimensions, and time scales have not contributed to define a unified concept for WUE and, more importantly, a common strategy to improve it (Hsiao et al., 2007). In this article we will refer to what agronomists often call "on-farm application efficiency" or "field application efficiency," defined as the fraction of the water volume that is consumed by a crop relative to the amount of applied water. We will mainly refer to vegetable crops, which use a minor share of the total water used for crop irrigation [in Italy 7\% (Istituto Nazionale di Economia Agraria, 2007)]. Generally, vegetables are crops with higher economic value and productivity per unit of applied water compared with field crops. In commercial vegetable productions, irrigation is crucial to achieve high economic returns, in terms of both yield and product quality. That is why farmers tend to overirrigate vegetable crops and, consequently, to reduce irrigation efficiency. It must be stressed that, at farm level, water is not only used to fulfil crop evapotranspiration (ET) requirements but also for other purposes, including the distribution of fertilizers and/or pesticides and postharvest washing. All these variables define potential water use inefficiency niches that will be discussed in the following sections.

\section{Crop WUE}

At plant level, the ratio of plant biomass over the evapotranspired water is used to define WUE and is considered a measure of plant's efficiency in using water. At crop level, WUE is calculated as the transformation efficiency of water, through the cultivation system into yield, according to the formula:

$$
\begin{aligned}
\text { water use efficiency }= & \frac{\text { yield }}{W}=\frac{\text { biomass }}{E+T+\text { losses }} \\
& \times H I,
\end{aligned}
$$

where, $W$ is the global amount of water available (natural rainfall and irrigation), $T=$ transpiration, $E=$ evaporation, losses $=$ amount of water lost at any level of the process, $H I=$ harvest index. As it is difficult to separate $E$ and $T$ components, they are usually included in the term ET.

Water use efficiency can be improved by modifying both terms of the ratio. Agronomic techniques aimed at reducing water losses (at irrigation, field or plant levels) and effectively conveying water to the root zone will increase WUE. Similarly any agronomic practice that will increase crop yield will ultimately enhance WUE. Other criteria to improve WUE may involve controlling physiological processes that affect plant transpiration and yield. In this respect, our understanding of abscisic acid (ABA) mechanism of perception and signaling has greatly advanced. This will likely open new avenues for developing commercial products that modulate/control $\mathrm{ABA}$ action to improve plants WUE (Weiner et al., 2010). It has been recently demonstrated that overexpression of NCED, a key gene in ABA biosynthesis, may cause stomatal closure and reduce transpiration without affecting $\mathrm{CO}_{2}$ assimilation and biomass accumulation (Thompson et al., 2007).

At plant and leaf levels, WUE can be expressed as the ratio between the $\mathrm{CO}_{2}$ fixed by photosynthesis and water lost through transpiration. Leaf transpiration, which is driven by the vapor pressure difference between inside and outside the leaf, encounters stomatal, cuticular, and boundary layer resistances. The transpiration rate increases linearly with stomatal conductance $\left(g_{\mathrm{S}}\right)$ as net $\mathrm{CO}_{2}$ assimilation does, but the latter saturates at high $g_{s}$ due to enzymatic (rubisco) limitation. It is possible to improve WUE by reducing stomatal density and stomatal aperture, cuticular transpiration, and boundary layer conductance, the latter being related to leaf surface size and shape, roughness and presence of trichoma (Yoo et al., 2009).

Variable WUEs among crop species are mainly associated to different carboxylation pathways (Ludlow and Muchow, 1990). For instance, the three groups of plants $(\mathrm{C} 3, \mathrm{C} 4$, and crassulacean acid metabolism) have increasing transpiration efficiency (WUE), with C4 species commonly having twice the WUE of C3 species (i.e., the majority of vegetable crops). Genetic variation among genotypes within the same plant species has been documented, suggesting that WUE is under genetic control (Yoo et al., 2009).

Breeding efforts over the past 50 years have been successful at producing new, high yield cultivars, but yield increases have also resulted in higher crop water consumption. Growth and yield are generally linearly related to the amount of water transpired by a crop throughout the growing season (Bassil and Kaffka, 2002). A simple analysis of the data available in the literature (Hutmacher et al., 1990; Smittle et al., $1990,1994)$ reveals that marketable yield of vegetable crops such as snapbean (Phaseolus vulgaris) and carrot (Daucus carota) increases linearly with increasing irrigation, regardless of edible organ or year (Fig. 1). There are at least three possible explanations for the linear relationship between yield and crop water consumption: 1) $\mathrm{CO}_{2}$ and water vapor share a common diffusive pathway at the leaf surface; consequently, stomata must be open and water transpired in order for crops to assimilate carbon from air surrounding leaves; 2) both water loss and photosynthesis are driven by absorption of light (Amthor, 1999); or 3) transpiration significantly cools leaves and canopies, which alleviates high temperature stress (Lu et al., 1998). In other words, the same adaptation traits that favor fast growth in crop plants (e.g., leaves with large surface areas, short diffusive pathways from the leaf interior to the atmosphere, and high $g_{s}$ ) also favor water loss.

As general rule, WUE can be enhanced through an appropriate choice of crop/cultivars and implementation of strategies that identify the best match between crop type 
and time of cultivation for a specific environment. These practices include selecting the most suitable and adapted species/cultivar for specific pedoclimatic conditions, and optimizing the timing for planting/harvesting (Fig. 2).
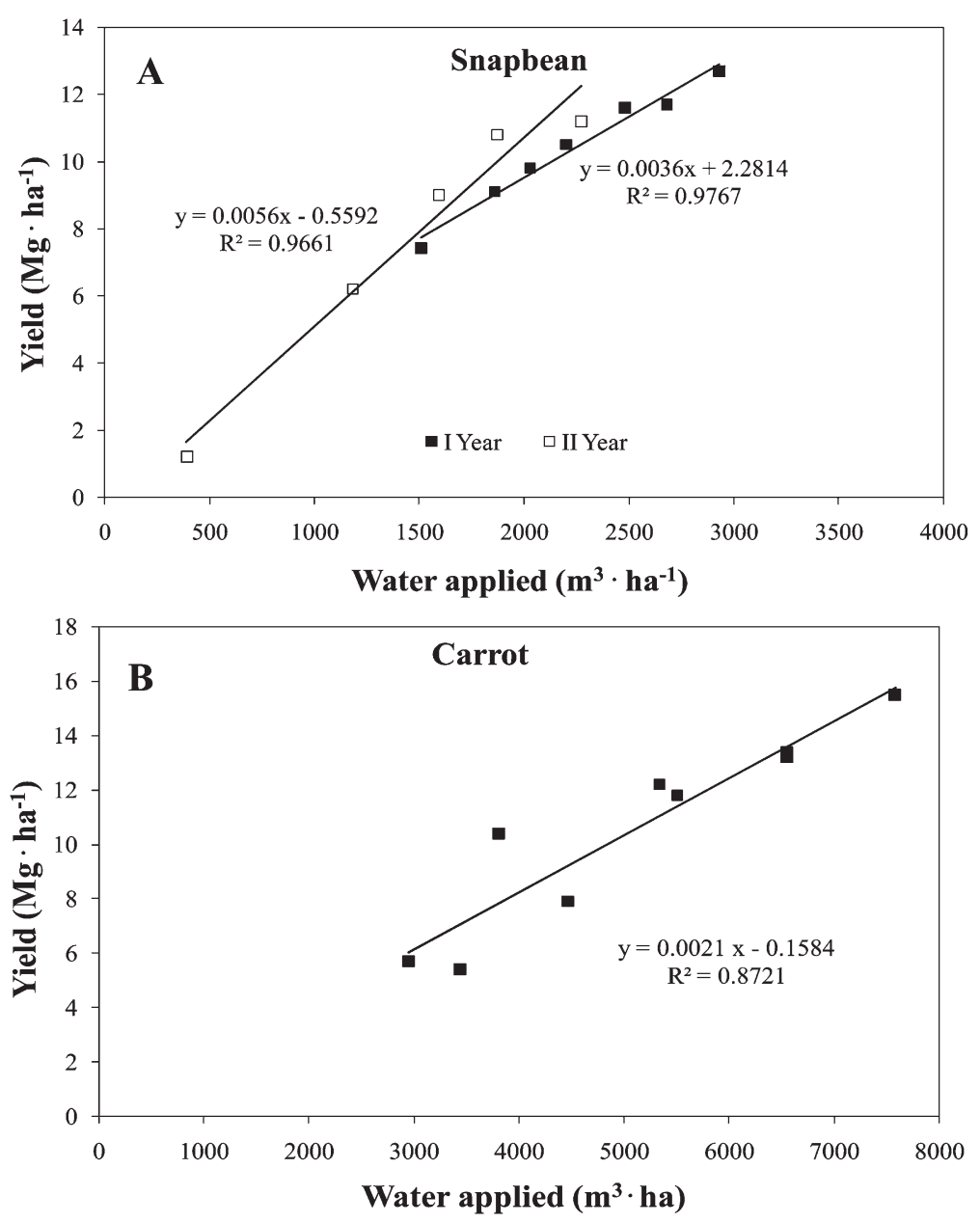

Fig. 1. Linear regression between yield and applied water for (A) snapbean and (B) carrot (Daucus carota) (adapted from Smittle et al., 1990; Hutmacher et al., 1990, respectively); $1 \mathrm{~m}^{3} \cdot \mathrm{ha}^{-1}=14.2913 \mathrm{ft}^{3} / \mathrm{acre}, 1 \mathrm{Mg} \cdot \mathrm{ha}^{-1}=0.4461 \mathrm{ton} /$ acre.

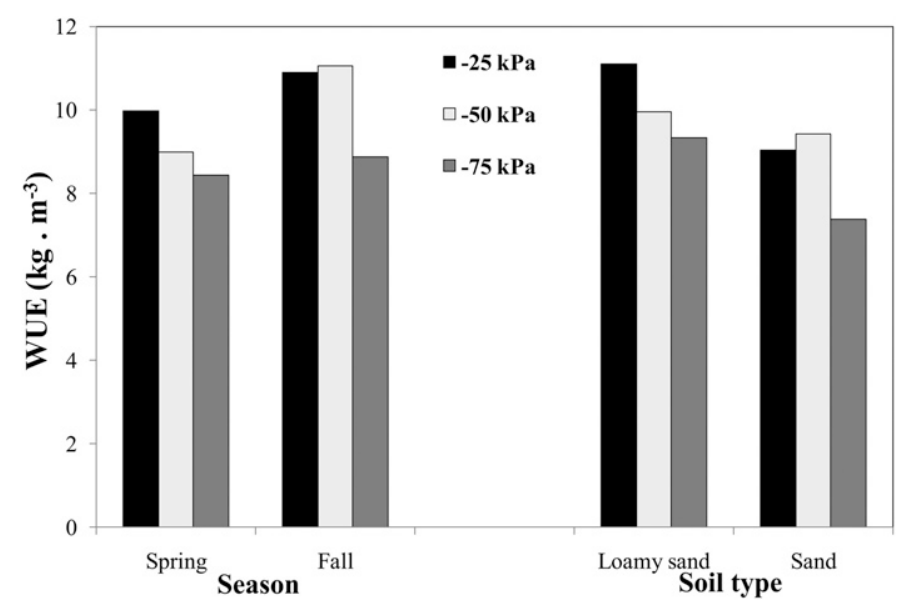

Fig. 2. Water use efficiency of bell pepper with respect to growing season (spring and fall), soil type [loamy sand soil $(\mathbf{8 0 . 4 \%}$ sand, $9 \%$ silt, $7 \%$ clay, and $3.6 \%$ organic matter) and sand soil (92.1\% sand, $2.0 \%$ silt, $4.1 \%$ clay, and $1.8 \%$ organic matter)], and irrigation regime (irrigation at soil water tensions of $-25,-50$, or $-75 \mathrm{kPa}$ ) (adapted from Smittle et al., 1994); $1 \mathrm{~kg} \cdot \mathrm{m}^{-3}=0.0624 \mathrm{lb} / \mathrm{ft}^{3}, 1 \mathrm{kPa}=1 \mathrm{cbar}$.

To increase WUE at farm level, the objective should be maximizing the cultivated area during periods of low environmental demand for ET and/or period when rainfall has a greater likelihood of occurrence, which may both have beneficial effects on WUE (Hatfield et al., 2001; Hsiao et al., 2007). This can be obtained by shifting planting dates in the field or considering protected cultivation strategies that would consent to control climatic variables and decrease crop ET (Baille, 2001).

Over the years, crop WUE has increased mostly because of higher harvest index and improved efficiency of irrigation methods rather than increased biomass production per unit of water consumed (Passioura, 2006). During the past 40 years of tomato (Solanum lycopersicum) cultivation in California, ET rates have remained relatively steady at an average of 650 $\mathrm{mm}$, but yields have increased more than 50\% (Hanson and May, 2006).

In irrigated vegetables production, it is important to reduce water loss through evaporation from the soil uncovered by vegetation. This can be accomplished by achieving a rapid and uniform soil coverage through transplanting rather than direct sowing (Leskovar et al., 2001) and choice of optimal density and planting geometry (Hsiao et al., 2007). In tomato, decreasing the row spacing from 0.7 to $0.5 \mathrm{~m}$ and $0.35 \mathrm{~m}$ increased fruit yield when drip irrigation was used (Yohannes and Tadesse, 1998). Similarly, closer row spacing and higher densities in combination with a reduced irrigation regime provided the highest WUE and economic yield in lima beans [Phaseolus lunatus (Sirait et al., 1994)].

The benefit of mulch in the production of vegetable crops is well established. Plastic mulches are used to increase soil temperature, control weeds, and consequently improve crop yields. Plastic mulches reduce nutrient leaching, and stabilize soil moisture (Zajicek and Heilman, 1991), which in turn may enhance rapid and uniform crop soil coverage and increase yield. The light reflected from the surface of plastic mulch can improve the growth of tomato (Decoteau et al., 1989) and bell pepper [Capsicum annuum (Decoteau et al., 1990; Roberts and Anderson, 1994)]. Although plastic mulching may require 
specialized labor and equipment for fertilization and water management, drip systems and fertigation may increase yields of mulched vegetable crops (Roberts and Anderson, 1994). Weed control measures significantly contribute to increase crop WUE by reducing competition for nutrients and moisture in the root zone and for light aboveground (Putnam, 1990). Nelson and Thoreson (1981) reported that weed emergence within a potato (Solanum tuberosum) crop (58-311 weeds $/ \mathrm{m}^{2}$ ) may reduce tuber yield up to $54 \%$ with negative effects on WUE.

Increasing soil nutrient status has been demonstrated to have a positive effect on WUE. For vegetable crops, fertigation is often recommended (Hartz and Hochmuth, 1996; Hatfield et al., 2001). Results obtained in lysimeters with potato and tomato (Dalla Costa and Giovanardi, 2000) grown at increasing nitrogen $(\mathrm{N})$ fertilization rate $\left(0,100,200 \mathrm{~kg} \cdot \mathrm{ha}^{-1} \mathrm{~N}\right)$ under three irrigation regimes $(70 \%$, $100 \%$ of full ET and irrigated with $120 \%$ ET) confirmed an increase of WUE with the highest $\mathrm{N}$ rate $(200$ $\mathrm{kg} \cdot \mathrm{ha}^{-1} \mathrm{~N}$ ) and adequate water availability (100\% of full ET). A limited water shortage $(70 \%$ of full ET) is in some cases beneficial, especially if applied in coincidence with the less sensitive stages (i.e., during tuber bulking) (Dalla Costa and Giovanardi, 2000). Partial fulfilment of ET requirements is termed deficit irrigation and it is an important tool to increase WUE. Deficit irrigation implies a gradual increase in crop water stress, obtained by a uniform reduction of the amount of applied water (Fereres and Soriano, 2007). This practice is based on a prior knowledge of crop responses to water deficit and is increasingly used on fruit crops (Evans and Sadler, 2008). Specific techniques that impose partial water deficit have been developed in recent years. These include regulated deficit irrigation and controlled alternate partial root zone irrigation or partial root zone drying, which have been proposed to improve field and fruit crop WUE (Kang and Zhang, 2004).

Excessive irrigation [irrigation with $120 \%$ of full ET (ET120)] resulted in lower WUE due to deep percolation and leaching, whereas $\mathrm{N}$ distribution with fertigation proved to increase WUE (Fig. 3).

\section{Irrigation efficiency}

The competition for freshwater often implies that water for irrigation is not always available in the required quantity and/or quality (Food and Agriculture Organization of the United Nations, 2002). Therefore, farmers often have to manage irrigation under moderate or severe water shortage. Allocation of limited water supplies is central to irrigation management decisions, whether at the field, farm, irrigation-district or river-basin level. Key issues for irrigation water management are: 1) how much water is needed to satisfy crops demand, 2) when irrigation is needed, and 3 ) how to supply water to the crop (i.e., choice of the irrigation method). The first question has been exhaustively studied in classical experiments aimed at defining yield response curves to increasing applied water. These responses are generally described by an asymptotic curve (Fig. 4). A substantial amount of data on water requirements is available for major field vegetable crops (Allen et al., 1998; Brouwer and Heibloem, 1986; Tognoni et al., 2002).

According to the general response curve displayed in Fig. 4, three different objectives can be achieved: 1 )

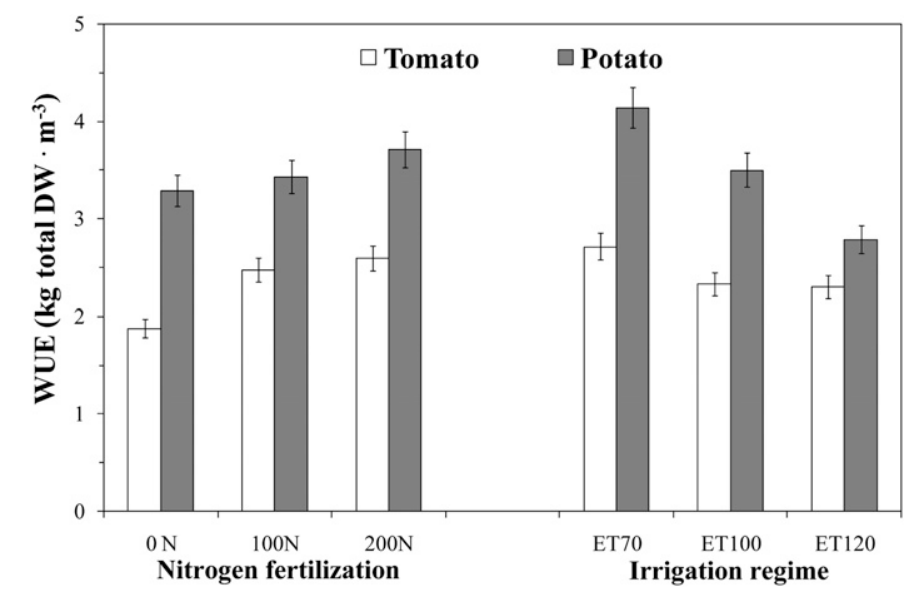

Fig. 3. Effects of different quantities of nitrogen $(\mathrm{N})$ and water applied on water use efficiency of tomato and potato: $0 \mathrm{~N}, 100 \mathrm{~N}$, and $200 \mathrm{~N}=0,100$, and $200 \mathrm{~kg} \cdot \mathrm{ha}^{-1} \mathrm{~N}$, respectively; ET70 = water shortage with $70 \%$ cumulative evapotranspiration (ET); ET100 = adequate water availability with $100 \%$ cumulative ET; ET1 $20=$ overirrigated with $120 \%$ cumulative ET. Mean values $\pm \mathrm{SE}$ (adapted from Dalla Costa and Giovanardi, 2000); $1 \mathrm{~kg} \cdot \mathrm{ha}^{-1}=0.8922 \mathrm{lb} / \mathrm{acre}, 1 \mathrm{~kg} \cdot \mathrm{m}^{-3}=0.0624 \mathrm{lb} / \mathrm{ft}^{3}$.

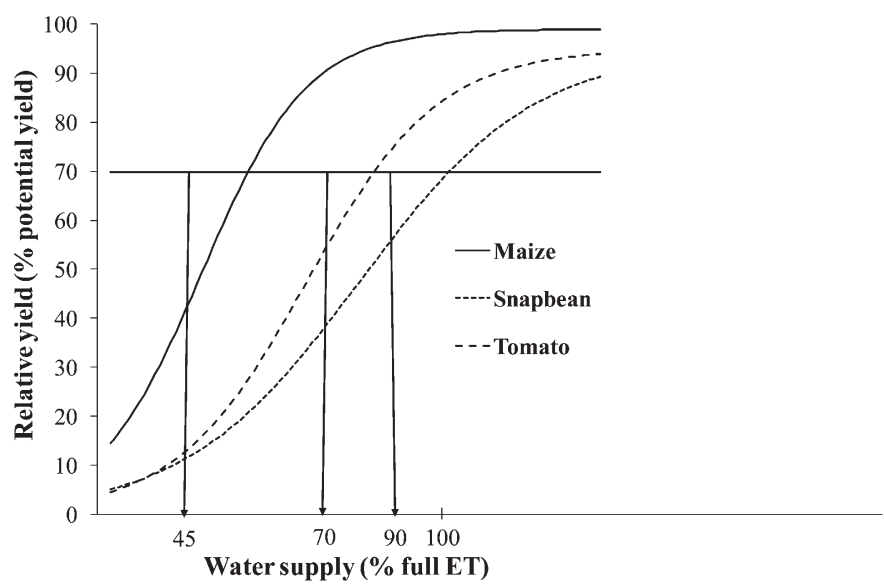

Fig. 4. General dose-response curves of crop yield to irrigation. For high marginal productivity crops such as maize, $70 \%$ of the potential maximum yield is obtained with seasonal water supply corresponding to $45 \%$ of the full evapotranspiration

(ET) requirements; whereas for low marginal productivity crops such as tomato and snapbean, the same yield value is obtained with irrigation volumes varying between $70 \%$ and $90 \%$ of the full ET (adapted from De Pascale et al., 2006). 
maximizing the crop yield (i.e., maximizing the crop productivity per unit of land area) by replenishing the full crop ET requirements, 2) maximizing the crop WUE (i.e., maximizing the crop productivity per unit of water consumed), and 3) maximizing the farmer's economic returns (i.e., maximizing the economic value of the crop yield per unit of land area).

With regard to vegetable crops, generally, yield decreases significantly in the absence of sufficient water to fully replenish ET. In addition, the negative effects of limited irrigation water on the quality of vegetable crops further contribute to a substantial reduction of the marketable yield. Vegetable crops are more sensitive (e.g., snapbean) or less sensitive (e.g., tomato) to suboptimal irrigation with slight differences among cultivars (Allen et al., 1998).

For crops with high marginal productivity of applied water, such as maize (Zea mays), $70 \%$ of the maximum yield is obtained with seasonal water supply corresponding to $45 \%$ of the full ET requirements, whereas for low marginal water productivity crops (tomato and snapbean) the same yield value is obtained with irrigation volumes varying between $70 \%$ and $90 \%$ of the full ET (Fig. 4). In long-term field experiments, Oster et al. (1986) have found irrigation efficiencies exceeding $70 \%$ for most crops, but lowest values were found for lettuce (Lactuca sativa) and cantaloupe (Cucumis melo). Deficit irrigation strategies would require an accurate assessment of growth stage-specific stress tolerances for vegetable crops (Upchurch et al., 2005 ) and optimal water management supported by advanced irrigation systems; i.e., able to promptly cope with crop water requirements at sensitive phenological stages (Evans and Sadler, 2008). However, in semiarid environments, the fulfilment of leaching requirements significantly limits the possibility of applying deficit irrigation criteria and reduces the WUE in irrigated vegetable production (Fig. 5).

The proper time for irrigation respect to plant water requirements can be defined based on the following general criteria: 1) estimation of the soil moisture (e.g., visual appreciation of the "soil dryness" and/or use of tensiometers, soil moisture sensors, and neutron meters), 2) evaluation of plant water stress (e.g., visual appreciation of incipient wilting; measurements of $g_{S}$, leaf water potential, and leaf temperature via infrared thermometry), and 3) assessment based on micrometeorological parameters (e.g., measurements of ET using evaporimeters and atmometers or estimates using mathematical models). Computer software has been developed to continuously monitor micrometeorological parameters for prediction purposes and species-specific irrigation schedules (Pardossi et al., 2009). These systems are sufficiently accurate and can be linked to specific support services for growers and complete automation (Pardossi et al., 2009). Irrigation programming can greatly improve WUE. The adoption of methods to control the level of plant water stress (using soil tensiometers or other soil water sensors or calculation of water balance) can reduce the amount of water applied to the crop up to $53 \%$ (MuňozCarpena et al., 2008; Tognoni et al., 2002). However, comparative analyses among different strategies are limited (Table 1). Regarding the choice of the irrigation method (Fig. 6), average irrigation efficiencies can vary from $25 \%$ to $50 \%$ for furrow irrigation systems, from $50 \%$ to $70 \%$ for the sprinkler systems, from $80 \%$ to $90 \%$ for the trickle (or drip) irrigation. If the amount of water is limited, sprinkler and drip methods can increase the irrigated area by $20 \%$ to $30 \%$ and $30 \%$ to $40 \%$, respectively compared with furrow irrigation (Tognoni et al., 2002). In addition, irrigation water management with high flow turnouts and level basin irrigation systems can increase the efficiency of surface irrigation. Low energy precision application and spray irrigation also improve irrigation efficiency (Schneider and Howell, 1999).

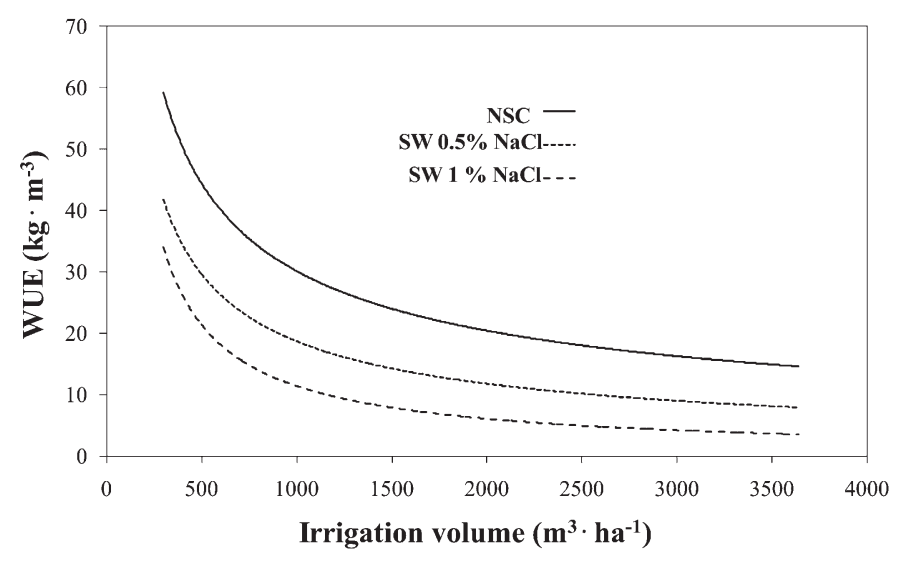

Fig. 5. Water use efficiency of cabbage as affected by the salinity of the irrigation water. The experimental treatments were a nonsalinized control and irrigation with saline water containing $\mathbf{0 . 5 \%}$ or $\mathbf{1} \%$ of sodium chloride (adapted from Maggio et al., $2005) ; 1 \mathrm{~m}^{3} \cdot \mathrm{ha}^{-1}=14.2913 \mathrm{ft}^{3} / \mathrm{acre}, 1 \mathrm{~kg} \cdot \mathrm{m}^{-3}=0.0624 \mathrm{lb} / \mathrm{ft}^{3}$.

Table 1. Relative efficiency and reduction of the irrigation volume for different irrigation scheduling strategies compared with the fix interval and volume approach (adapted from Barbieri and Pascale, 2010).

\begin{tabular}{lcc}
\hline Strategy & $\begin{array}{c}\text { Relative } \\
\text { efficiency } \\
(\%)\end{array}$ & $\begin{array}{c}\text { Reduction of } \\
\text { irrigation volume } \\
(\%)\end{array}$ \\
\hline Fix interval and volume & 100 & 0 \\
Plant phenology & 115 & 13 \\
Microclimate (historical data) & 130 & 23 \\
Soil moisture (tensiometers) & 140 & 29 \\
Soil moisture (Bouyoucos blocks) & 150 & 33 \\
Microclimate (collected data) & 160 & 38 \\
Combined (water balance) & 170 & 41 \\
Plant water status (pressure chamber) & 175 & 43 \\
Combined (estimated evapotranspiration & 215 & 53 \\
$\quad$ and tensiometers) & & \\
\hline
\end{tabular}


Drip irrigation is very common in greenhouse horticulture. Higher yields, improved WUE, and higher produce quality have been reported for drip irrigation systems compared with other irrigation methods for different vegetable crops, including potato (Unlu et al., 2006), cucumber [Cucumissatious (Yuan et al., 2006)], bell pepper (Sezen et al., 2006), okra [Abelmoschus esculentus (Tiwari et al., 1998)], cabbage [Brassica oleracea Capitata group (Tiwari et al., 2003)], eggplant [Solanum melongena (Aujla et al., 2006)], and watermelon [Citrullus lanatus (Srinivas et al., 1989)].

Some advantages of drip irrigation include improved water and nutrient management, improved saline water management, potential for improved yields and crop quality, and greater control of applied water resulting in less water and nutrient loss through deep percolation.

Use of subsurface drip irrigation has progressed from being a novelty used only in experimental fields to an accepted method of irrigation for both tree and vegetable crops (Lamm and Camp, 2007). Subsurface drip irrigation on lettuce (Thompson and Doerge, 1995), tomato, sweet corn (Z. mays), and cantaloupe (Ayars et al., 1999) has significantly increased yield and WUE in all these crops. Subsurface drip irrigation may increase WUE in semiarid environment under saline conditions by increasing yield (Ayars et al., 1999). However, the choice of the proper irrigation technology is highly site-specific, reflecting regional (field characteristics and climate), technical (water supply and crop characteristics), and market (crop prices, energy cost, labor supply) factors (Wichelns, 2007). Subsurface drip irrigation can potentially provide a more stable soil water and nutrient environment for optimal crop growth, and also be effective for salinity management, soil water redistribution, and application of agrochemicals (Lamm and Camp, 2007). Farmers producing high-value crops in arid and semiarid regions have a greater likelihood of benefiting from adopting drip irrigation and subsurface drip irrigation than farmers producing low-value crops in humid and subhumid climates (Wichelns, 2007). Alternate furrow irrigation is another technique that appears promising (Kang et al., 2000).
In many circumstances, the effectiveness of improved irrigation practices may be enhanced when implemented in combination with other farming practices such as nutrient management. Aujla et al. (2006) have demonstrated on eggplant that determining the exact quantity of water to be delivered through drip irrigation at different levels of nitrogen $(\mathrm{N})$ is essential for optimizing water and nitrogen use efficiency while achieving highest yield (Fig. 7).

Drip irrigation, for instance, allows growers to deliver supplemental fertilizers to mulched crops enhancing yield and produce quality (Tiwari et al., 1998, 2003).

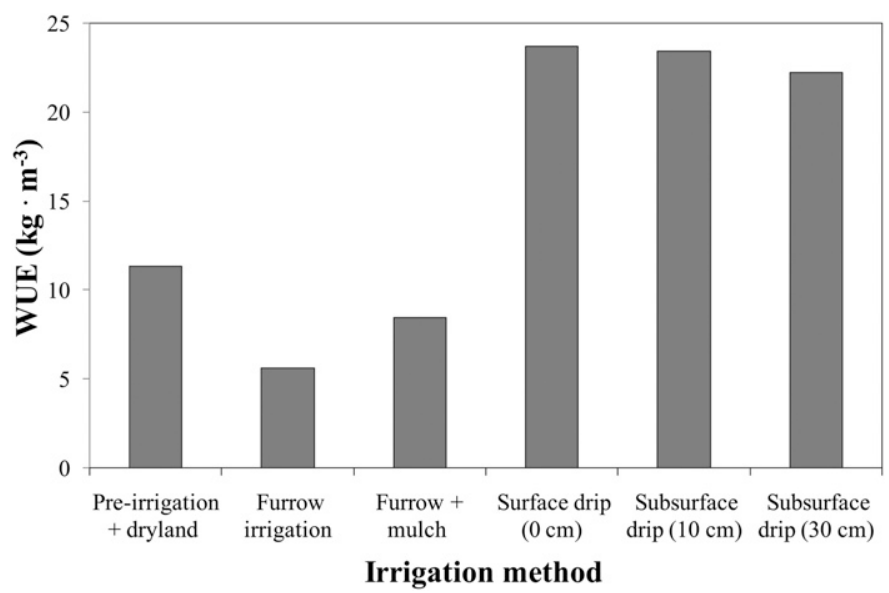

Fig. 6. Water use efficiency of 'Caravelle' cantaloupe as affected by the irrigation method (mean values of 4 years). Irrigation efficiencies of three irrigation systems (furrow, sprinkler, and drip irrigation) were compared (adapted from Leskovar et al., 2001); $1 \mathrm{~cm}=0.3937 \mathrm{inch}, 1 \mathrm{~kg} \cdot \mathrm{m}^{-3}=0.0624 \mathrm{lb} / \mathrm{ft}^{3}$.

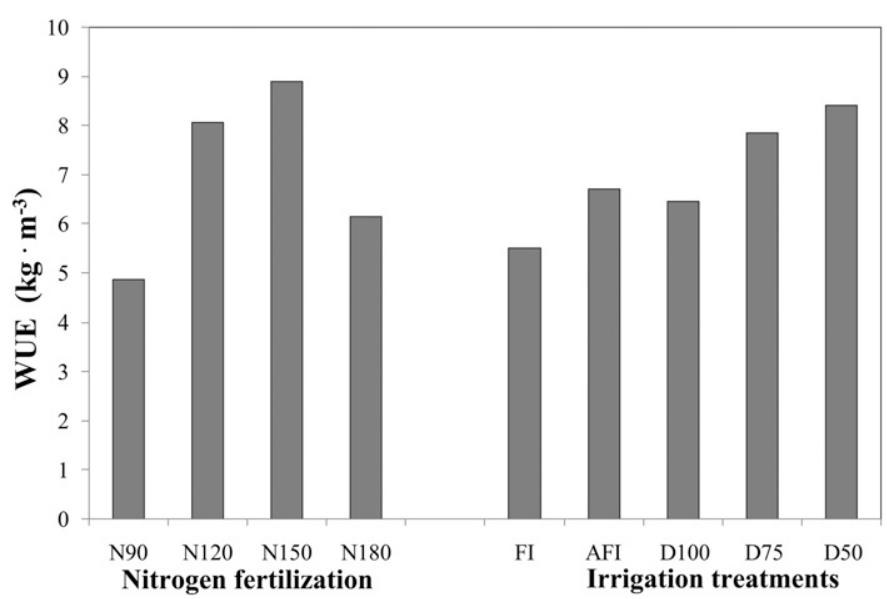

Fig. 7. Effects of different quantities of nitrogen $(\mathrm{N})$ and water applied through drip and furrow irrigation on fruit yield and water use efficiency of eggplant: N90, N120, N150, and N180 =90, 120, 150, and $180 \mathrm{~kg} \cdot \mathrm{ha}^{-1} \mathrm{~N}$, respectively; D100, $\mathrm{D} 75$, and D50 = drip irrigation to $100 \%, 75 \%$, and $50 \%$ cumulative pan evaporation, respectively; $\mathrm{FI}=$ furrow irrigation, $\mathrm{AFI}=$ alternate furrow irrigation (adapted from Aujla et al., 2006); $1 \mathrm{~kg} \cdot \mathrm{ha}^{-1}=0.8922 \mathrm{lb} / \mathrm{acre}, 1 \mathrm{~kg} \cdot \mathrm{m}^{-3}=0.0624 \mathrm{lb} / \mathrm{ft}^{3}$. 
limited understanding of the molecular basis and physiological mechanisms regulating WUE in stressed and nonstressed plants.

Targeted agronomic practices such as the choice of appropriate crop/cultivar for a specific environment as well as planting and harvesting times, adequate plant nutrition, soil management, and weed control can significantly contribute to improve WUE.

There are various irrigation techniques to enhance the efficiency of the applied water to the crop. Improving irrigation techniques can directly affect WUE by increasing the yield per unit of water applied and reducing the amount of water loss (i.e., increasing the amount of water used by the crop per unit of water applied). Major improvements could be obtained through management and innovative design of integrated water delivery and application schemes. Innovative decision support systems integrated by sensor networks to monitor soil and plant water status will help farmers to efficiently allocate limited water resources.

\section{Literature cited}

Allen, R.G., L.S. Pereira, D. Raes, and M. Smith. 1998. Crop evapotranspiration: Guidelines for computing crop water requirements. Irr. Drainage Paper No. 56. Food and Agriculture Organization of the United Nations, Rome.

Amthor, J.S. 1999. Increasing atmospheric $\mathrm{CO}_{2}$ concentration, water use, and water stress: Scaling up from the plant to the landscape, p. 33-59. In: Y. Luo and H.A. Mooney (eds.). Carbon dioxide and environmental stress. Academic Press, San Diego.

Aujla, M.S., H.S. Thind, and G.S. Buttar. 2006. Fruit yield and water use efficiency of eggplant (Solanum melongena L.) as influenced by different quantities of nitrogen and water applied through drip and furrow irrigation. Sci. Hort. 112: $142-148$.

Ayars, J.E., C.J. Phene, R.B. Hutmacher, K.R. Davis, R.A. Schoneman, S.S. Vail, and R.M. Mead. 1999. Subsurface drip irrigation of row crops: A review of 15 years of research at the Water Management Research Laboratory. Agr. Water Mgt. 42:1-27.

Baille, A. 2001. Trends in greenhouse technology for improved climate control in mild winter climates. Acta Hort. 599:161-168.
Barbieri, G. and S. De Pascale. 2010. Strategie di irrigazione ed efficienza d'uso dell'acqua nelle colture ortive da pieno campo. Italus Hortus 17:1-9.

Bassil, E.S. and S.R. Kaffka. 2002. Response of safflower (Carthamus tinctorius L.) to saline soils and irrigation: I. Consumptive water use. Agr. Water Mgt. 54:67-80.

Brouwer, C. and M. Heibloem. 1986. Irrigation water management: Irrigation water needs. In: Training Manual No. 3: Irrigation water needs. Food and Agriculture Organization of the United Nations, Rome.

Dalla Costa, L. and R. Giovanardi. 2000. Nitrogen use efficiency in tomato and potato as affected by water regime and $\mathrm{N}$ fertilisation, p. 443-447. In: G. Parente and J. Frame (eds.). Proc. COST 814 Final Conf., 10-13 May 2000, Pordenone, Italy.

Decoteau, D.R., M.J. Kasperbauer, and P.G. Hunt. 1989. Mulch surface color affects yield of fresh-market tomatoes. J. Amer. Soc. Hort. Sci. 114:216-219.

Decoteau, D.R., M.J. Kasperbauer, and P.G. Hunt. 1990. Bell pepper plant development over mulches of diverse colors. HortScience 25:460-462.

De Pascale, S., A. Maggio, and G. Barbieri. 2006. La sostenibilità delle colture protette in ambiente mediterraneo: Limiti e prospettive. Italus Hortus 13:33-48.

Evans, R.G. and E.J. Sadler. 2008. Methods and technologies to improve efficiency of water use. Water Resources Res. 44:1-15.

Fereres, E. and M.A. Soriano. 2007. Deficit irrigation for reducing agricultural water use. J. Expt. Bot. 58:147-159.

Food and Agriculture Organization of the United Nations. 2002. Crops and drops: Making the best use of water for agriculture Natural Resources Environ. Dept., FAO, Rome.

Hanson, B.R. and D.M. May. 2006. Crop coefficients for drip-irrigated processing tomato. Agr. Water Mgt. 81:381-399.

Hartz, T.K. and G.J. Hochmuth. 1996. Fertility management of drip-irrigated vegetables. HortTechnology 6:168-172.

Hatfield, J.L., T.J. Sauer, and J.H. Prueger. 2001. Managing soil to achieve greater water use efficiency: A review. Agron. J. 93:271-280.

Hsiao, T.C., P. Steduto, and E. Fereres. 2007. A systematic and quantitative approach to improve water use efficiency in agriculture. Irr. Sci. 25:209-231.

Hutmacher, R.B., J.J. Steiner, J.E. Ayars, A.B. Mantel, and S.S. Vail. 1990. Response of seed carrot to various water regimes. I. Vegetative growth and plant water relations. J. Amer. Soc. Hort. Sci. 115:715721.

Istituto Nazionale di Economia Agraria. 2007. Uso irriguo dell'acqua e principali implicazioni di natura ambientale. INEA, Rome.

Jensen, M.E. 2007. Beyond irrigation efficiency. Irr. Sci. 25:233-245.

Kang, S.Z., Z.S. Liang, Y.H. Pan, P.Z. Shi, and J.H. Zhang. 2000. Alternate furrow irrigation for maize production in an arid area. Agr. Water Mgt. 45:267-274.

Kang, S.Z. and J.H. Zhang. 2004. Controlled alternate partial root-zone irrigation: Its physiological consequences and impact on water use efficiency. J. Expt. Bot. 55:2437-2446.

Lamm, F.R. and C.R. Camp. 2007. Subsurface drip irrigation, p. 473-551. In: F.R. Lamm, J.E. Ayars, and F.S. Nakayama (eds.). Microirrigation for crop production: Design, operation, and management. Elsevier, Amsterdam, The Netherlands.

Leskovar, D.I., J.C. Ward, W. Russell, R.W. Sprague, and A. Meiri. 2001. Yield, quality, and water use efficiency of muskmelon are affected by irrigation and transplanting versus direct seeding. HortScience 36:286-291.

Lu, Z.M., R.G. Percy, C.O. Qualset, and E. Zeiger. 1998. Stomatal conductance predicts yields in 417 irrigated Pima cotton and bread wheat grown at high temperatures. J. Expt. Bot. 49:453-460.

Ludlow, M.M. and R.C. Muchow. 1990. A critical evaluation of traits for improving crop yields in water-limited environments. Adv. Agron. 43:107-153.

Maggio, A., S. De Pascale, C. Ruggiero, and G. Barbieri. 2005. Physiological response of field-grown cabbage to salinity and drought stress. Eur. J. Agron. 23:57-67.

Morison, J.I.L., N.R. Baker, P.M. Mullineaux, and W.J. Davies. 2008. Improving water use in crop production. Phil. Trans. Royal Soc. B 363:639-658.

Muňoz-Carpena, R., M.D. Dukes, Y. Li, and W. Klassen. 2008. Design and field evaluation of a new controller for soilwater based irrigation. Appl. Eng. Agr. 24:183-191.

Nelson, D.C. and M.C. Thoreson. 1981. Competition between potatoes (Solanum tuberosum) and weeds. Weed Sci. 29:672677.

Oster, J.D., J.L. Meyer, L. Hermsmeier, and M. Kaddah. 1986. Field studies of irrigation efficiency in the Imperial Valley. Hilgardia 54:1-15. 
Pardossi, A., L. Incrocci, G. Incrocci, F. Malorgio, P. Battista, L. Bacci, B. Rapi, P. Marzialetti, J. Hemming, and J. Balendonck. 2009. Root zone sensors for irrigation management in intensive agriculture. Sensors (Basel Switzerland) 9:2809-2835

Passioura, J. 2006. Increasing crop productivity when water is scarce: From breeding to field management. Agr. Water Mgt. 80:176-196.

Postel, S. 1999. Pillar of sand: Can the irrigation miracle last? Norton, New York.

Putnam, A.R. 1990. Vegetable weed control with minimal herbicide inputs. HortScience 25:155-158.

Roberts, B.W. and J.A. Anderson. 1994. Canopy shade and soil mulch affect yield and solar injury of bell pepper. HortScience 29:258-260.

Rockström, J. and M. Falkenmark. 2000. Semiarid crop production from a hydrological perspective: Gap between potential and actual yields. Crit. Rev. Plant Sci. 19:319-346.

Schneider, A.D. and T.A. Howell. 1999. LEPA and spray irrigation for grain crops. J. Irr. Drain. Eng. 125:167-172.

Sezen, S.M., A. Yazar, and J.L. Eker. 2006. Effect of drip irrigation regimes on yield and quality of field 11 grown bell pepper. Agr. Water Mgt. 81:115-131.

Sinclair, T.R., C.B. Tanner, and J.M. Bennett. 1984. Water-use efficiency in crop production. Bioscience 34:36-40.

Sirait, Y., W.G. Pill, and W.E. Kee, Jr. 1994. Lima bean (Phaseolus lunatus L.) response to irrigation regime and plant population density. HortScience 29:71-73.

Smittle, D.A., W.L. Dickens, and J.R. Stansell. 1990. An irrigation scheduling model for snap bean. J. Amer. Soc. Hort. Sci. 115:226-230.
Smittle, D.A., W.L. Dickens, and J.R. Stansell. 1994. Irrigation regimes affect yield and water use by bell pepper. J. Amer. Soc. Hort. Sci. 119:936-939.

Srinivas, K., D.M. Hegde, and G.V. Havanagi. 1989. Irrigation studies of watermelon (Citrullus lanatus (Thunb) Matsum et Nakai). Irr. Sci. 10:293-301.

Thompson, A.J., J. Andrews, B.J. Mulholland, J.M. McKee, H.W. Hilton, J.S. Horridge, G.D. Farquhar, R.C. Smeeton, I.R. Smillie, C.R. Black, and I.B. Taylor. 2007. Overproduction of abscisic acid in tomato increases transpiration efficiency and root hydraulic conductivity and influences leaf expansion. Plant Physiol. 143:1905-1917.

Thompson, T.L. and T.A. Doerge. 1995 Nitrogen and water rates for subsurface trickle-irrigated romaine lettuce. HortScience 30:1233-1237.

Tiwari, K.N., P.K. Mal, R.M. Singh, and A. Chattopadhyay. 1998. Response of okra (Abelmoschus esculentus L.) to drip irrigation under mulch and non-mulch conditions. Agr. Water Mgt. 38:91-102.

Tiwari, K.N., S. Singh, and P.K. Mal. 2003. Effect of drip irrigation on yield of cabbage (Brassica oleracea L. var. capitata) under mulch and non-mulch conditions. Agr. Water Mgt. 58:19-28.

Tognoni, F., G. La Malfa, G. Barbieri, G. Serra, A. Maggio, and C. Leonardi. 2002. Some aspects of the vegetable industry in Italy. Acta Hort. 582:121-133.

Unlu, M., R. Kanber, U. Senyigit, H. Onaran, and K. Diker. 2006. Trickle and sprinkler irrigation of potato (Solanum tuberosum L.) in Middle Anatolian Region in Turkey. Agr. Water Mgt. 79:43-71.

Upchurch, D.R., J.R. Mahan, D.F. Wanjura, and J.J. Burke. 2005. Concepts in deficit irrigation: Defining a basis for effective management. Paper No. 9028. Proc.
World Water Environ. Resources Congr., 15-19 May 2005. Anchorage, AK.

Wallace, J.S. 2000. Increasing agricultural water use efficiency to meet future food production. Agr. Ecosystem Environ. 82:105-119.

Wallace, J.S. and P.J. Gregory. 2002. Water resources and their use in food production system. Aquat. Sci. 64:363375.

Weiner, J.J., F.C. Peterson, B.F. Volkman, and S.R. Cutler. 2010. Structural and functional insights into core $\mathrm{ABA}$ signaling. Curr. Opin. Plant Biol. 13: 495-502.

Wichelns, D. 2007. Economic implications of microirrigation, p. 221-259. In: Lamm F.R., Ayars J.E., and F.S. Nakayama (eds.). Microirrigation for crop production: Design, operation, and management. Elsevier, Amsterdam, The Netherlands.

Yohannes, F. and T. Tadesse. 1998. Effect of drip and furrow irrigation and plant spacing on yield of tomato at Dire Dawa, Ethiopia. Agr. Water Mgt. 35:201-207.

Yoo, C.Y., H.E. Pence, P.M. Hasegawa, and M.V. Mickelbart. 2009. Regulation of transpiration to improve crop water use. Crit. Rev. Plant Sci. 28:410-431.

Yuan, B.-Z., J. Sun, Y. Kang, and S. Nishiyama. 2006. Response of cucumber to drip irrigation water under a rainshelter. Agr. Water Mgt. 81:145-158.

Zajicek, J.M. and J.L. Heilman. 1991. Transpiration by crape myrtle cultivars surrounded by mulch, soil, and turfgrass surfaces. HortScience 26:12071210 . 